\title{
An Assessment of Degradation of Soil Properties in Kabba College of Agriculture, Kogi State, Nigeria
}

\author{
Babalola, T. S. ${ }^{1}{ }^{*}$, Ogunleye, K. S. ${ }^{2}$, Lawal, J. A. ${ }^{1}$ and Ilori, A. O. A. ${ }^{2}$ \\ ${ }^{1}$ Kabba College of Agriculture, Division of Agricultural Colleges, Ahmadu Bello University, Kabba, Kogi State, \\ Nigeria \\ ${ }^{2}$ Department of Soil Science and Land Management, Federal University Oye-Ekiti, Ikole Campus, Ekiti State, \\ Nigeria \\ Corresponding Author: *drbabalolatemitopeseun@gmail.com
}

https://doi.org/10.36263/nijest.2021.01.0240

\begin{abstract}
Some soils in Kabba College of Agriculture, Kogi State, southern guinea savannah zone of Nigeria, were assessed to ascertain the levels of degradation of soil properties. The rigid grid soil survey method was used to identify seven soil units. Soils were sampled at 0-20 cm and 20-40 cm soil depth and analyzed for physical and chemical properties using standard methods. Levels of degradation were obtained by comparing laboratory data with the standard land/soil requirement (indicators/criteria) for grouping lands into different degradation classes of 1 to 4 (non to slightly, moderately, highly, and very highly degraded). Results showed that units $D$ (soghum) and $E$ (citrus) were very highly degraded (Class 4) of exchangeable potassium; units $C$ (yam), D and $E$ were highly degraded (Class 3 ) of organic matter. Other units were moderately degraded (Class 2) of base saturation, bulk density and total nitrogen. There was no degradation of available phosphorus and exchangeable sodium percentage in all the units. Physical and chemical degradation took place in the study area with respect to bulk density, base saturation, total nitrogen, potassium, and organic matter. Sustainable management practices that will promote good bulk density and organic matter accumulation should be encouraged.
\end{abstract}

Keywords: Degradation, Assessments, Chemical, Physical, Indicators

\subsection{Introduction}

The threats to land by soil degradation have been the subject for intensive debate in the literature (Baumhardt et al., 2015). In Africa, an estimated 500 million hectares of land have been affected by soil degradation including agricultural land (Wynants et al., 2019). Its devastating effects have subjected local communities to high risks of loss of lives, properties and land resource that supports their livelihood.

In the world, there is practically no extensive area of land without limitation of one sort or another (Ibrahim and Idogba, 2013). Indiscriminate forest cleaning and burning, inappropriate land cultivation, over grazing, improper irrigation practice, urban development and high population density have no doubt contributed to changes in the landscape. More than 75 percent of Earth's land areas are substantially degraded, undermining the well-being of 3.2 billion people, according to the world's first comprehensive, evidence-based assessment (Leahy, 2018).

According to Idoga et al. (2007) land degradation is a universal set while soil degradation is derived from land degradation since soil is the most stable and most manipulated feature of the land. The major human activity that contributes to soil degradation is agriculture (Food and Agriculture Organization-FAO, 2005). Continuous and inappropriate land use systems have severely impaired the soil. It has been reported that every land use partly destroys the soil structure and reduces soil fertility (Altieri and Nicholis, 2003). 
There have been many reports on implication of different land uses on soil properties and fertility, (Yusuf et al., 2019; Yusuf et al., 2015; Malgwi and Abu, 2011; Cobo et al., 2010; Martensson, 2009) and other works on soil degradation assessment that examines the actual level, nature and forms in different agroecological zones of Nigeria (Adewuyi et al., 2019; Senjobi et al., 2013; Ibrahim and Idogba, 2013; Sotona, et al. 2013; Adewuyi 2011; Isirimah, 2005; Igwe, 2003). In Kabba College of Agriculture, Kabba, Kogi State the major land utilization type is agriculture involving intensive, continuous cropping and mechanization but there are no studies on soil degradation. Available report is on soil quality in relation to crop yield along toposequence (Babalola et al., 2012); therefore, the need for this study arises. The objective of this study is to identify and document the actual level, nature and forms of soil degradation in the study area.

\subsection{Materials and Method}

\subsection{Description of the study area}

Kabba is located in Kogi State, Kabba/Bunu Local Government Area in the Southern Guinea Savannah Agro-ecological zone of Nigeria. Kabba College of Agriculture is located on latitude $7^{0} 51$ ' $\mathrm{N}$ and longitude $6^{0} 04^{\prime} \mathrm{E}$. It has climate that is typical of humid tropics with rainfall that spans the month of May to October. The dry season extends from November to April. The vegetation of the area is dominated by tall grasses and shrubs. Also, human activities have influenced the vegetation in the area (Babalola et al., 2012). The area belongs to the basement complex geology of Nigeria (Obaje, 2009).

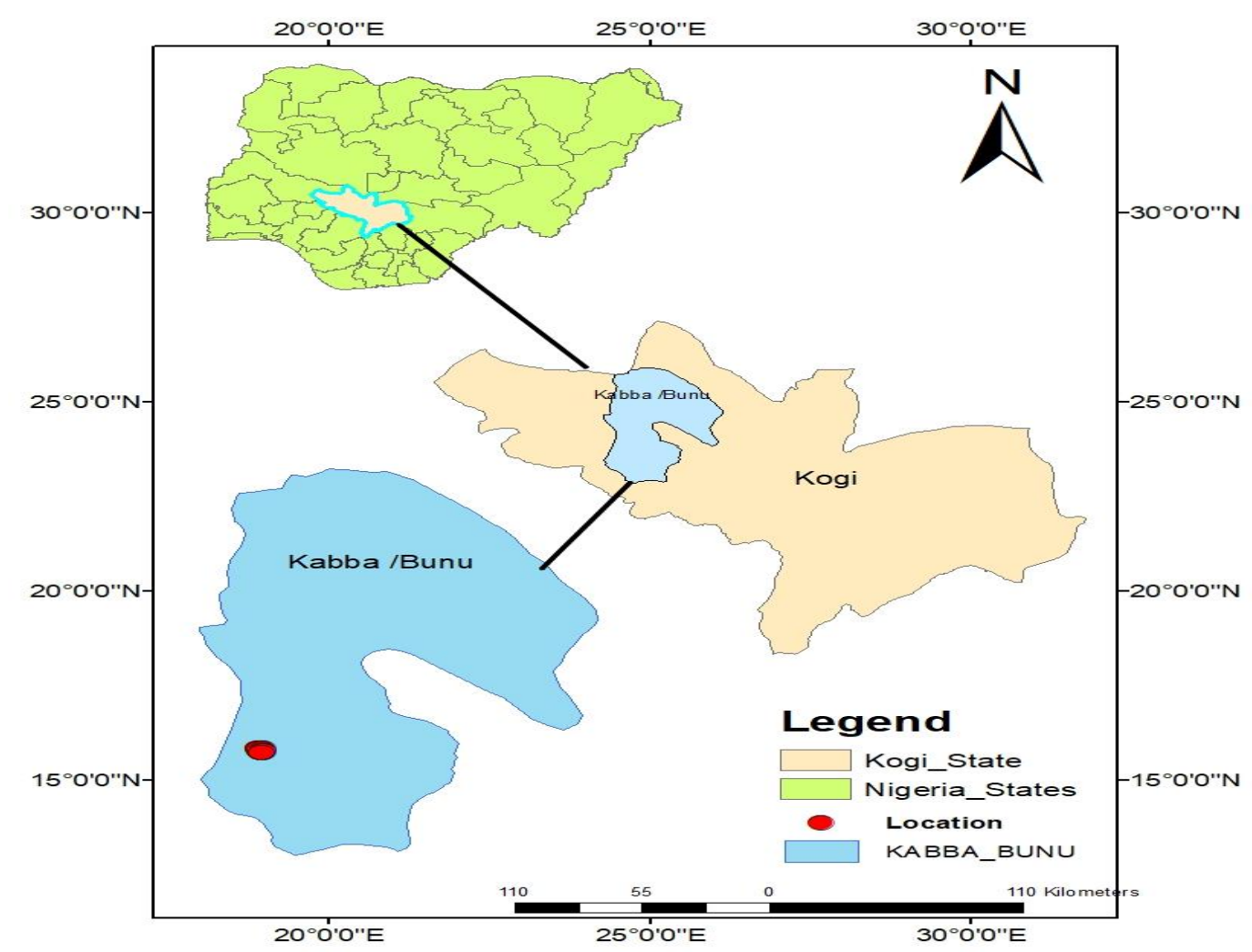

Figure 1: Map showing the location of the study within, Nigeria, Kogi State and Kabba/Bunu Local Government

\subsection{Land use}

The major land use type in the area is arable crop land involving cultivation of crops such as maize, sorghum, rice, cassava, yam, pepper and dry season vegetable production in the wetland portion of the area. Also, tree crops such as oil palm, banana, pineapple and citrus are cultivated in some part of the area. Tillage practices in the area involved the use of simple implements while ploughing, harrowing, and ridging is practiced in some part. 


\subsection{Field work and sampling}

The rigid grid soil survey method following the guidelines of Soil Survey Staff, (2014) was used to sample the soils. Soils were probed at $100 \mathrm{~m}$ within traverse and the colour, texture, consistence, and structure were determined. Areas with similar characteristics were identified as soil units and were labelled with the prominent agricultural land use within the unit (Figure 2) as follows: Cassava-A, Oil palm- B, Yam- C, Sorghum- D, Citrus- E, Maize- F and Pasture- G. Within each soil unit a representative area was selected and soil samples were collected at $0-20 \mathrm{~cm}$ and $20-40 \mathrm{~cm}$ soil depth using auger. Core sample were also collected for the determination of bulk density and saturated hydraulic conductivity.

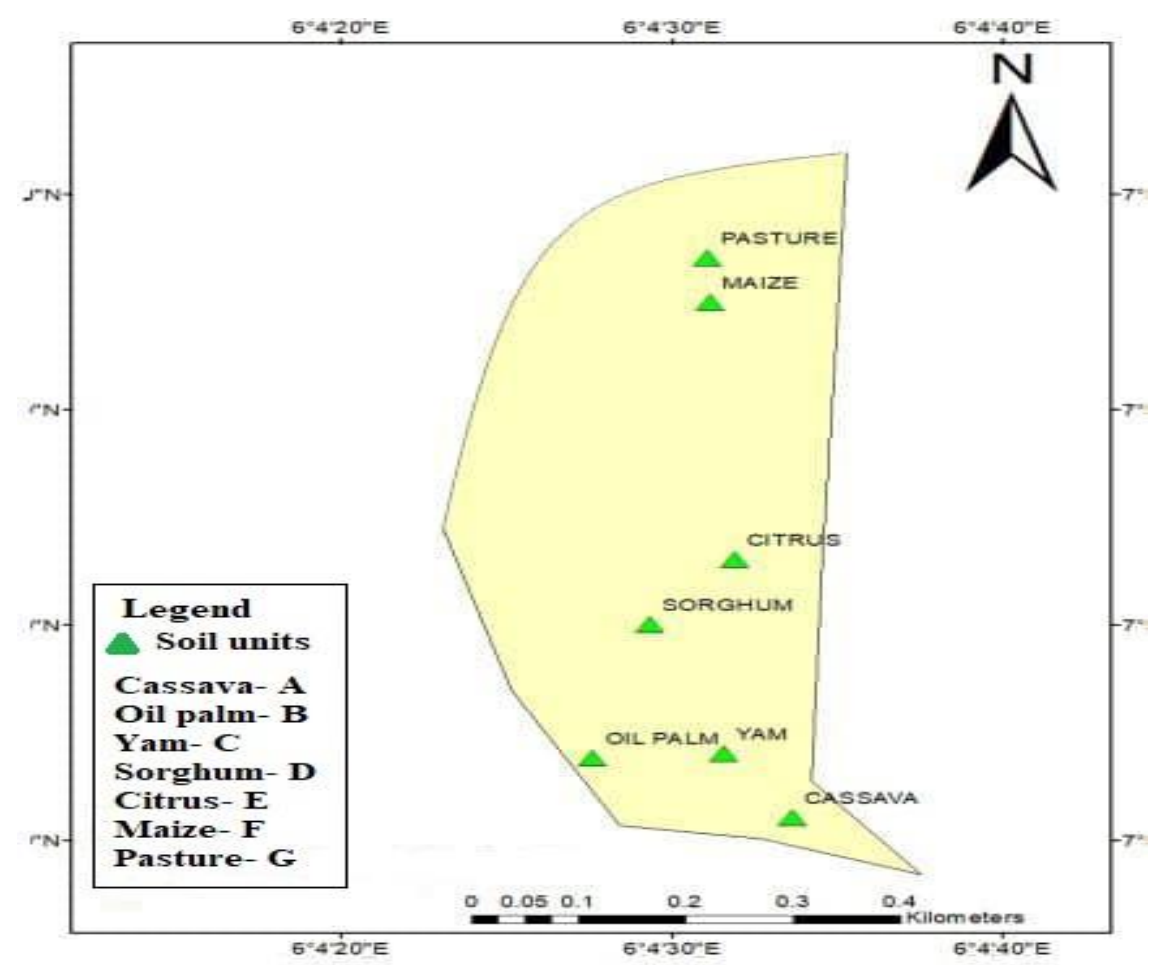

Figure 2: Map of the location showing the sampling points and agricultural land use of soil units

\subsection{Soil analysis}

The bulk samples were air dried, gently crushed and passed through a $2 \mathrm{~mm}$ sieve. Core samples were trimmed to the height of the core sampler for bulk density determination. Particle size distribution, $\mathrm{pH}$, organic carbon, total nitrogen, available phosphorus, exchangeable bases, and exchangeable acidity were determined following the International Institute for Tropical Agriculture IITA, (1979) guidelines. The effective cation exchanges capacity, base saturation, and exchange sodium percentages were calculated.

\subsection{Land degradation assessment}

The levels of degradation of the soil were assessed using the standard indicator and criteria for degradation assessment (Tables 1 - 3) (FAO, 1979; Snakin et al., 1996; Senjobi et al., 2013).

Analytical data from each sample were placed in a degradation class by matching the soil characteristics with the land degradation indicator. The estimates of the degree of degradation were based on the measured physical and chemical parameters.

Table 1: Indicators and criteria of physical degradation of soil

\begin{tabular}{|c|c|c|c|c|c|}
\hline \multirow[t]{2}{*}{ Indicator } & \multicolumn{5}{|c|}{$*$ Degree of degradation $(\%)$} \\
\hline & Initial Level & 1 & 2 & 3 & 4 \\
\hline Soil bulk density $\left(\mathrm{g} / \mathrm{cm}^{3}\right)$ & $1.25-1.4$ & $<1.5$ & $1.5-2.5$ & $2.5-5$ & $>5$ \\
\hline Permeability $(\mathrm{cm} / \mathrm{hr})$ & $5-10$ & $<1.25$ & $1.25-5$ & $5-10$ & $>20$ \\
\hline $\begin{array}{r}\text { Sources: FA } \\
\text { *Where 1. Non to slig } \\
\text { 2. Moderately } \\
\text { 3. Highly de } \\
\text { 4. Very high }\end{array}$ & $\begin{array}{l}\text { 1979), Snakin } \\
\text { degraded so } \\
\text { aded soil whe } \\
\text { led soil where } \\
\text { aded soil wh }\end{array}$ & $\begin{array}{l}\text { (1996) } \\
\text { ere proc } \\
\text { oductiv } \\
\text { ductivity } \\
\text { roductiv }\end{array}$ & $\begin{array}{l}\text { jobi et al } \\
\text { vity range } \\
\text { anges fror } \\
\text { ges from } \\
\text { anges fror }\end{array}$ & $\begin{array}{l}013) \\
\text { om } 75- \\
0-75 \% \\
50 \% \\
-25 \%\end{array}$ & \\
\hline
\end{tabular}


Table 2: Indicators and criteria of chemical degradation of soil

\begin{tabular}{|c|c|c|c|c|}
\hline \multirow[t]{2}{*}{ Indicator } & \multicolumn{4}{|c|}{ *Degree of degradation $(\%)$} \\
\hline & 1 & 2 & 3 & 4 \\
\hline Content of Nitrogen Element (Multiple decrease) N (\%) & $>0.13$ & $0.10-0.13$ & $0.08-0.10$ & $<0.08$ \\
\hline Content of Phosphorus Element (mg/kg) & $>8$ & $7-8$ & $6-7$ & $<6$ \\
\hline Content of Potassium Element $(\mathrm{cmol} / \mathrm{kg})$ & $>0.16$ & $0.14-0.16$ & $0.12-0.14$ & $<0.12$ \\
\hline $\begin{array}{l}\text { Content of Exchangeable Sodium Percentage (ESP) (Increase by } 1 \% \\
\text { of CEC) }\end{array}$ & $<10$ & $10-25$ & $25-50$ & $>50$ \\
\hline Base Saturation (decrease of saturation in more than $50 \%$ ) & $<2.5 \%$ & $2.5-5 \%$ & $5-10 \%$ & $>10 \%$ \\
\hline Excess salt (Salinization) (Increase in conductivity (mmho/cm/yr) & $<2$ & $2-3$ & $3-5$ & $>5$ \\
\hline Content of organic matter in soil $(\%$ & $>2.5$ & $2-2.5$ & $1.0-2$ & $<1.0$ \\
\hline $\begin{array}{r}\text { Modified from: FAO (1979), Snakin et al. }(1 \\
\text { *Where 1. Non to slightly degraded soil where pro } \\
\text { 2. Moderately degraded soil where product } \\
\text { 3. Highly degraded soil where productivi } \\
\text { 4. Very high degraded soil where product }\end{array}$ & $\begin{array}{l}\text { 96), Senjo } \\
\text { luctivity } r \\
\text { ity ranges } \\
\text { ranges } f r \\
\text { ity ranges }\end{array}$ & $\begin{array}{l}\text { et al. }(2013) \\
\text { ges from } 75-1 \\
\text { om } 50-75 \% \\
\text { n } 25-50 \% \\
\text { rom } 0-25 \%\end{array}$ & & \\
\hline
\end{tabular}

\subsection{Results and Discussion}

\subsection{Soil properties}

The physical and chemical properties of surface $(0-20 \mathrm{~cm})$ and subsurface $(20-40 \mathrm{~cm})$ of the studied area are presented in Table 3 and 4, respectively. All the seven (7) soil units show differences in the surface and subsurface horizons. Bulk density values were higher in units A, C, E, F, and G in the subsurface horizons $\left(1.60,1.65,1.75,1.67\right.$ and $1.50 \mathrm{~g} / \mathrm{cm}^{3}$ respectively) than the surface horizons $\left(1.58,1.49,1.50,1.55\right.$ and $1.39 \mathrm{~g} / \mathrm{cm}^{3}$ respectively) while the opposite exists for units B and D (1.55 and $1.49 \mathrm{~g} / \mathrm{cm}^{3}, 1.40$ and $1.48 \mathrm{~g} / \mathrm{cm}^{3}$ respectively). The trend of distribution of bulk density between the soils studied can be attributed to differences in clay and soil organic matter (Ibrahim and Idogba, 2013). Idoga et al. (2007) state that soil organic matter is light and tends to lower bulk density when present in high amount in the soil. The result of the total porosity mostly follows the same pattern as bulk density. Particle size analysis shows decrease in sand content and increase in clay content in most of the units from the surface to subsurface horizons; this is typical of soils developed on basement complex areas in Nigeria and in agreement with reports of Babalola et al. (2012) for some soils in Kabba, Kogi State.

There are differences between the surface and subsurface horizons of chemical properties of soils. Soil $\mathrm{pH}$, organic carbon, total nitrogen, available phosphorus, exchangeable cations, and Cation Exchange Capacity (CEC) are higher in the surface horizon of the soil units studied. These differences may be attributed to the production of humus in the surface horizon and cultivation practices.

Table 3: Physical properties of the soil units

\begin{tabular}{|c|c|c|c|c|c|c|c|c|}
\hline $\begin{array}{l}\text { Soil } \\
\text { Unit/Land } \\
\text { use }\end{array}$ & $\begin{array}{l}\text { Depth } \\
\text { (cm) }\end{array}$ & $\begin{array}{c}\text { Bulk } \\
\text { Density } \\
\left(\mathrm{g} / \mathrm{cm}^{3}\right)\end{array}$ & $\begin{array}{c}\text { Total } \\
\text { Porosity }\end{array}$ & $\begin{array}{c}\text { Permeability } \\
\text { (K Sat) } \\
\text { (Cm/hr) }\end{array}$ & $\begin{array}{c}\text { Sand } \\
\%\end{array}$ & $\begin{array}{c}\text { Silt } \\
\%\end{array}$ & Clay\% & Textural Class \\
\hline \multirow[t]{2}{*}{ A (Cassava) } & $0-20$ & 1.58 & 56 & 0.71 & 70 & 11 & 19 & Sandy Loam \\
\hline & $20-40$ & 1.60 & 45 & 0.65 & 71 & 09 & 20 & Sandy Loam \\
\hline \multirow[t]{2}{*}{ B (Oil palm) } & $0-20$ & 1.59 & 59 & 0.64 & 77 & 03 & 20 & Sandy Loam \\
\hline & $20-40$ & 1.55 & 50 & 0.52 & 71 & 13 & 16 & Sandy Loam \\
\hline \multirow[t]{2}{*}{ C (Yam) } & $0-20$ & 1.49 & 68 & 0.97 & 79 & 02 & 19 & Sandy Loam \\
\hline & $20-40$ & 1.65 & 51 & 1.01 & 39 & 08 & 53 & Sandy Clay \\
\hline \multirow[t]{2}{*}{ D (Sorghum) } & $0-20$ & 1.48 & 50 & 0.86 & 75 & 06 & 19 & Sandy Loam \\
\hline & $20-40$ & 1.40 & 35 & 3.09 & 62 & 08 & 30 & Clay Loam \\
\hline \multirow[t]{2}{*}{ E (Citrus) } & $0-20$ & 1.50 & 49 & 1.81 & 73 & 13 & 14 & Sandy Loam \\
\hline & $20-40$ & 1.75 & 37 & 1.71 & 60 & 08 & 32 & $\begin{array}{l}\text { Sandy Clay } \\
\text { Loam }\end{array}$ \\
\hline \multirow[t]{2}{*}{ F (Maize) } & $0-20$ & 1.55 & 65 & 2.71 & 35 & 26 & 39 & Clay Loam \\
\hline & $20-40$ & 1.67 & 55 & 1.91 & 46 & 19 & 35 & $\begin{array}{l}\text { Sandy Clay } \\
\text { Loam }\end{array}$ \\
\hline \multirow[t]{2}{*}{ G (Pasture) } & $0-20$ & 1.39 & 60 & 0.95 & 48 & 25 & 27 & Loam \\
\hline & $20-40$ & 1.50 & 41 & 0.88 & 57 & 21 & 22 & Sandy Loam \\
\hline
\end{tabular}


Table 4: Chemical properties of the soil units

\begin{tabular}{|c|c|c|c|c|c|c|c|c|}
\hline \multirow[t]{2}{*}{ Soil Properties } & \multicolumn{8}{|c|}{ Soil Units } \\
\hline & $\begin{array}{c}\text { Soil } \\
\text { Depth } \\
\text { (cm) }\end{array}$ & A & B & $\mathrm{C}$ & $\mathrm{D}$ & $\mathrm{E}$ & $\mathrm{F}$ & $\mathrm{G}$ \\
\hline \multirow{2}{*}{$\mathrm{pH}\left(\mathrm{H}_{2} \mathrm{O}\right)$} & $0-20$ & 5.95 & 6.14 & 5.67 & 5.51 & 6.22 & 5.97 & 4.97 \\
\hline & $20-40$ & 5.85 & 6.11 & 5.65 & 4.82 & 5.98 & 5.83 & 4.81 \\
\hline \multirow[t]{2}{*}{ Organic Carbon (\%) } & $0-20$ & 1.68 & 1.85 & 1.12 & 1.24 & 0.89 & 2.53 & 2.70 \\
\hline & $20-40$ & 1.44 & 1.70 & 0.96 & 1.01 & 0.84 & 1.98 & 2.09 \\
\hline \multirow[t]{2}{*}{ Organic Matter (\%) } & $0-20$ & 2.89 & 3.18 & 1.93 & 2.13 & 1.53 & 4.35 & 4.64 \\
\hline & $20-40$ & 2.48 & 2.92 & 1.65 & 1.74 & 1.45 & 3.41 & 3.60 \\
\hline \multirow[t]{2}{*}{ Total Nitrogen (\%) } & $0-20$ & 0.121 & 0.114 & 0.116 & 0.170 & 0.162 & 0.180 & 0.179 \\
\hline & $20-40$ & 0.103 & 0.088 & 0.109 & 0.110 & 0.157 & 0.165 & 0.161 \\
\hline \multirow[t]{2}{*}{ Available Phosphorus (mg/kg) } & $0-20$ & 49.75 & 22.26 & 41.92 & 9.19 & 10.40 & 32.41 & 18.97 \\
\hline & $20-40$ & 40.18 & 19.15 & 39.11 & 7.82 & 9.69 & 30.97 & 17.65 \\
\hline \multirow[t]{2}{*}{ Exchangeable Sodium (cmol/kg) } & $0-20$ & 0.201 & 0.235 & 0.190 & 0.190 & 0.231 & 0.180 & 0.210 \\
\hline & $20-40$ & 0.196 & 0.213 & 0.189 & 0.169 & 0.207 & 0.179 & 0.198 \\
\hline \multirow{2}{*}{$\begin{array}{l}\text { Exchangeable Potassium } \\
(\mathrm{cmol} / \mathrm{kg})\end{array}$} & $0-20$ & 0.229 & 0.180 & 0.235 & 0.073 & 0.102 & 0.258 & 0.201 \\
\hline & $20-40$ & 0.229 & 0.175 & 0.221 & 0.064 & 0.097 & 0.237 & 0.199 \\
\hline \multirow[t]{2}{*}{ Exchangeable Calcium (cmol/kg) } & $0-20$ & 3.76 & 2.80 & 4.32 & 2.90 & 6.56 & 2.72 & 3.04 \\
\hline & $20-40$ & 3.28 & 2.72 & 4.16 & 2.86 & 6.40 & 2.56 & 2.98 \\
\hline \multirow{2}{*}{$\begin{array}{l}\text { Exchangeable Aluminum } \\
(\mathrm{cmol} / \mathrm{kg})\end{array}$} & $0-20$ & 0.01 & 0.01 & 0.01 & 0.02 & 0.01 & 0.02 & 0.01 \\
\hline & $20-40$ & 0.01 & 0.01 & 0.01 & 0.01 & 0.01 & 0.02 & 0.01 \\
\hline \multirow{2}{*}{$\begin{array}{l}\text { Exchangeable Hydrogen } \\
(\mathrm{cmol} / \mathrm{kg})\end{array}$} & $0-20$ & 0.15 & 0.15 & 0.12 & 0.13 & 0.14 & 0.13 & 0.11 \\
\hline & $20-40$ & 0.13 & 0.14 & 0.12 & 0.11 & 0.12 & 0.13 & 0.11 \\
\hline \multirow[t]{2}{*}{ Exchangeable Bases (cmol/kg) } & $0-20$ & 5.830 & 5.005 & 6.115 & 5.083 & 7.693 & 4.118 & 5.761 \\
\hline & $20-40$ & 4.845 & 4.768 & 5.770 & 4.903 & 7.424 & 3.856 & 5.347 \\
\hline \multirow{2}{*}{$\begin{array}{l}\text { Cation Exchange Capacity } \\
(\mathrm{cmol} / \mathrm{kg})\end{array}$} & $0-20$ & 5.990 & 5.165 & 6.245 & 5.233 & 7.843 & 4.268 & 5.881 \\
\hline & $20-40$ & 4.985 & 4.918 & 5.900 & 5.023 & 7.554 & 4.006 & 5.467 \\
\hline \multirow[t]{2}{*}{ Base Saturation (\%) } & $0-20$ & 97.33 & 96.90 & 97.92 & 97.13 & 98.09 & 96.49 & 97.96 \\
\hline & $20-40$ & 97.19 & 96.95 & 97.80 & 97.61 & 98.28 & 96.26 & 97.81 \\
\hline \multirow{2}{*}{$\begin{array}{l}\text { Exchangeable Sodium Percentage } \\
(\%)\end{array}$} & $0-20$ & 3.45 & 4.70 & 3.11 & 3.74 & 3.00 & 4.37 & 3.65 \\
\hline & $20-40$ & 4.05 & 4.47 & 3.28 & 3.45 & 2.79 & 4.64 & 3.70 \\
\hline
\end{tabular}

\subsection{Land degradation assessment}

The land/soil requirement (indicators and criteria i.e. land qualities/soil properties) for grouping lands into different degradation classes are given in Table 1-2. The matching of the soil indicators/criteria are given in Table 5 .

The land degradation assessment results show that in terms of bulk density, only unit $\mathrm{D}$ was none degraded at both horizons, units $\mathrm{C}$ and $\mathrm{G}$ are none degraded at the surface and moderately degraded at the subsurface. Units A, B, E, and F are all moderately degraded at both horizons.

With respect to permeability, at the surface horizon, units A, B, C, E, and G are none degraded, unit D is highly degraded while unit $\mathrm{F}$ is moderately degraded.

Result of chemical properties showed that base saturation is moderately degraded in all the units; base saturation is an indicator of level of leaching, therefore this result signifies that the soils are moderately leached of their exchangeable bases.

Degradation assessment for total nitrogen shows that units E, F, and G are none degraded; Units A and $\mathrm{C}$ are moderately degraded at both horizons. Unit B is moderately degraded at the surface horizon and highly degraded at the subsurface. Unit D is non-degraded at the surface and moderately degraded at the subsurface.

Assessment for available phosphorus showed that all the soil units are non-degraded.

With respect to exchangeable Potassium; units A, B, C, F, and G are non-degraded while units D and E are very highly degraded at both horizons.

In terms of Exchangeable Sodium Percentage; all the units are non-degraded, indicating that the soils are not sodic. 
With respect to organic matter contents; units $\mathrm{B}, \mathrm{F}$, and $\mathrm{G}$ are non-degraded at the surface and subsurface. Unit A is non-degraded at the surface and moderately degraded at the subsurface. Unit D is moderately degraded at the surface and highly degraded at the subsurface. Units $\mathrm{C}$ and $\mathrm{E}$ are highly degraded in both horizons.

Physical and chemical degradation took place in the study area. Chemical degradation is as a result of loss of fertility from leaching and low organic matter. This might have occurred as a result of land use practices such as continuous cropping, improper handling of plant residues and bush burning. The soils can be ameliorated through improved and proper nutrient management practices (Eswaran and Dumanski, 1998; Senjobi et al., 2013). Physical degradation of soil could be as a result of tillage practices and improper soil management and it requires a long time to meliorate (Hulugalle, 1994; Senjobi et al., 2013).

Table 5: Land qualities/soil properties of the soil units

\begin{tabular}{|c|c|c|c|c|c|c|c|c|c|}
\hline $\begin{array}{l}\text { Soil } \\
\text { Unit/Land use }\end{array}$ & $\begin{array}{l}\text { Depth } \\
(\mathrm{cm})\end{array}$ & $\begin{array}{c}\text { Bulk } \\
\text { Density } \\
\left(\mathrm{g} / \mathrm{cm}^{3}\right)\end{array}$ & $\begin{array}{l}\text { Permeability } \\
(\mathrm{cm} / \mathrm{hr})\end{array}$ & $\begin{array}{c}\text { Base } \\
\text { Saturation } \\
(\%)\end{array}$ & $\begin{array}{l}\text { Total } \\
\mathrm{N}(\%)\end{array}$ & $\begin{array}{l}\text { Available } \\
\text { P (ppm) }\end{array}$ & $\begin{array}{c}\text { ExchK } \\
(\mathrm{cmol} / \mathrm{kg})\end{array}$ & $\begin{array}{l}\text { ESP } \\
(\%)\end{array}$ & $\begin{array}{c}\text { Organic } \\
\text { Matter } \\
(\%)\end{array}$ \\
\hline \multirow[t]{2}{*}{ A (Cassava) } & $0-20$ & 2 & 1 & 2 & 2 & 1 & 1 & 1 & 1 \\
\hline & $20-40$ & 2 & 1 & 2 & 2 & 1 & 1 & 1 & 2 \\
\hline \multirow[t]{2}{*}{ B (Oil palm) } & $0-20$ & 2 & 1 & 2 & 2 & 1 & 1 & 1 & 1 \\
\hline & $20-40$ & 2 & 1 & 2 & 3 & 1 & 1 & 1 & 1 \\
\hline \multirow[t]{2}{*}{ C (Yam) } & $0-20$ & 1 & 1 & 2 & 2 & 1 & 1 & 1 & 3 \\
\hline & $20-40$ & 2 & 1 & 2 & 2 & 1 & 1 & 1 & 3 \\
\hline \multirow[t]{2}{*}{ D (Sorghum) } & $0-20$ & 1 & 1 & 2 & 1 & 1 & 4 & 1 & 2 \\
\hline & $20-40$ & 1 & 3 & 2 & 2 & 1 & 4 & 1 & 3 \\
\hline \multirow[t]{2}{*}{ E (Citrus) } & $0-20$ & 2 & 1 & 2 & 1 & 1 & 4 & 1 & 3 \\
\hline & $20-40$ & 2 & 1 & 2 & 1 & 1 & 4 & 1 & 3 \\
\hline \multirow[t]{2}{*}{ F (Maize) } & $0-20$ & 2 & 2 & 2 & 1 & 1 & 1 & 1 & 1 \\
\hline & $20-40$ & 2 & 1 & 2 & 1 & 1 & 1 & 1 & 1 \\
\hline \multirow[t]{2}{*}{ G (Pasture) } & $0-20$ & 1 & 1 & 2 & 1 & 1 & 1 & 1 & 1 \\
\hline & $20-40$ & 2 & 1 & 2 & 1 & 1 & 1 & 1 & 1 \\
\hline & $\begin{array}{r}N-N \\
* W\end{array}$ & $\begin{array}{l}\text { ogen, Exc } \\
\text { re 1. Non } \\
\text { 2. Moder } \\
\text { 3. Higl } \\
\text { 4. Very }\end{array}$ & $\begin{array}{l}\text { K- Exchange } \\
\text { slightly degro } \\
\text { ly degraded } \\
\text { degraded so } \\
\text { gh degraded }\end{array}$ & $\begin{array}{l}\text { tassium, ES } \\
\text { d soil wher } \\
\text { where proc } \\
\text { here produ } \\
\text { where pro }\end{array}$ & $\begin{array}{l}\text { Excho } \\
\text { roduct } \\
\text { ctivity } \\
\text { ivity ra } \\
\text { ctivity }\end{array}$ & $\begin{array}{l}\text { eable Sodiv } \\
\text { ity ranges fr } \\
\text { iges from } 5 \\
\text { es from } 25- \\
\text { nges from } 0\end{array}$ & $\begin{array}{l}\text { Percentage } \\
75-100 \% \\
75 \% \\
\% \\
5 \%\end{array}$ & & \\
\hline
\end{tabular}

\subsection{Conclusions}

It is concluded that physical and chemical degradation took place in the study area with respect to bulk density, base saturation, total nitrogen, potassium, and organic matter. This study is considered as a preliminary project for the quality soil degradation assessment to develop sustainable practices to support the reclamation process and to develop a soil health program for the study area. Sustainable management practices that will promote good bulk density and organic matter accumulation should be adopted.

\section{References}

Adewuyi, T. O, Daful, M. G. and Olofin, E. A. (2019). Characterization of land degraded sites for restoration Along Kaduna-Abuja expressway, Chikun L.G.A. of Kaduna State Nigeria. Journal of Geography, 11(1), pp. $58-71$.

Adewuyi, T. O. (2011). Land Degradation in the peri-urban area: The case of Kaduna Metropolis, Nigeria. Lambert Academy Publishing, Germany. ISSN: 13 - 978-3847302490 158 pp.

Altieri, M. A. and Nicholis, C. (2003). Soil fertility and insect pests: Harmonizing soil and plant health in agro ecosystem. Soil and Tillage Research, 72, pp. 203-211.

Babalola, T. S., Oloniruha, J. A., Kadiri, W. O. J., Ogundare, S. K. and Tunku, P. (2012). Relationship between soil properties and yield of Amranthusvidris at two topo -locations within Kabba, Nigeria. A.B.U Journal of Vocational Studies, 6, pp. 178-180. 
Baumhardt, R. L., Stewart, B. A. and Sainju, U. M. (2015). North American soil degradation: processes, practices and mitigating strategies. Sustainability, 7, pp. 2936-2960.

Cobo, J. G., Dercon, G. and Cadisch, G. (2010). Nutrient balances in African land use systems across different spatial scales: A review of approaches, challenges and progress. Agriculture, Ecosystems \& Environment, 136(1-2), pp.1-15.

Eswaran, H. and Dumanski, J. (1998). Land degradation and sustainable agriculture: A global perspective. Proceedings of $8^{\text {th }}$ ISCO Conference New Delhi India. pp 208-225.

Food and Agriculture Organization (FAO) (2005). Agro-Ecological Zoning and GIS application in Asia with special emphasis on land degradation assessment in drylands (LADA). Proceedings of a Regional Workshop, Bangkok, Thailand10 14 November 2003. FAO. Accessed August 7, 2019, available on $\mathrm{ftp}: / / \mathrm{ftp}$. fao.org/agl/agll/docs/misc38e.pdf.

Food and Agriculture Organization (FAO) (1979). A provisional methodology for land degradation assessment. FAO. Rome.

Hulugalle, N. R. (1994). Long-term effect of land clearing methods, tillage systems and cropping system on surface soil properties of a tropical Alfisol in S. W. Nigeria. Soil use and Management, 10, pp. 25-80.

Ibrahim, M. M. and Idoga, S. (2013). Soil degradation assessment of the University of Agriculture, Makurdi students' industrial work experience scheme (SIWES) farm, Makurdi, Benue State. Pat. Journal. 9(2), pp. 126-135.

Idoga, S., Ibanga, I. J. and Malgwi, W. B. (2007).Variation in soil morphological and physical properties and their management implications on a toposequence in savanna Nigeria. In: Uyovbisere, E.O., Raji, B.A., Yusuf, A.A., Ogunwole, J.O., Aliyu, L. and Ojeniyi, S.O. editors. Soil and Water Management for Poverty Alleviation and Sustainable Environment. Proceedings of the $31^{\text {st }}$ Annual Conference of the Soil Science Society of Nigeria held at Ahmadu Bello University, Samaru Zaria. pp. 19-25.

Igwe, C. A. (2003). Soil degradation response to soil factors in central eastern Nigeria. In: Proceedings of the $28^{\text {th }}$ Annual Conference of Soil Science Society of Nigeria held at National Root Crops Research Institute, Umudike, pp. 228-234.

Isirimah, N. O. (2005). Land degradation, pollution and rehabilitation. In: Salako, F. K., Adetunji, M. T., Ojanuga, A. G., Arowolo, T. A. and Ojeniyi, S. O. editors. Managing soil resources for food security and sustainable environment. Proceeding of the $29^{\text {th }}$ Annual conference of the soil Science Society of Nigeria held at the University of Agriculture, Abeokuta, pp. 35-37.

IITA (1979). Selected methods for soil and plant analysis. $2^{\text {nd }}$ Ed., International Institute $\quad$ for Tropical Agriculture, Ibadan Oyo State, Nigeria. 70.

Leahy, S. (2018). land-degradation-environmental-damage-report.

https://www.nationalgeographic.com/news/2018/03/ipbes-land-degradation-environmental-damagereport-spd/

Malgwi, W. B. and Abu, S. T. (2011). Variation in some physical properties of soils form on a hilly terrain under different land use types in Nigeria savanna. International Journal of Soil Science, 6(3), pp.150-163.

Martensson, U. (2009). Extract from Assessment of Soil Degradation in Nigeria. SSC Satellitbild, SWECO International, and Niger Surveys and Consultants. Kiruna.

Obaje, N.G. (2009). Geology and mineral resources of Nigeria. Springer Dordrecht Heidelberg London New York. 219p. 
Senjobi, B. A., Ande, O. T. and Ogunkunle, A. O. (2013). Land degradation assessment under different uses: Implications on soil productivity and food security. Agronomski Glasnik. 1, pp. 3-21.

Soil Survey Staff (2014). Keys to soil taxonomy, $12^{\text {th }}$ ed. USDA-Natural Resources Conservation Service, Washington, DC.

Sotona, T., Salako, F. K. and Adesodun, J. K. (2013). Soil physical properties of selected soil series in relation to compaction and erosion on farmers' fields at Abeokuta, southwestern Nigeria. Archives of Agronomy and Soil Science, 60(6), pp. 841-857.

Sankin, V. V., Krechetor, P. P., Kuzovnikova, T. A., Alyabina, I. O., Gurov, A. F. and Steoichev, A. V. (1996). The system of assessment of soil degradation. Soil Technology. 8, pp. 331-343.

Wynants, M., Kelly, C., Mtei, K., Munishi, L., Patrick, A et al. (2019). Drivers of increased soil erosion in East Africa's agro-pastoral systems: Changing interactions between the social, economic and natural domains. Regional Environmental Change, https://doi.org/10.1007/s10113-019-01520-9

Yusuf, M. B., Abba, U. J and Isa, M. S. (2019). Assessment of soil degradation under agricultural land use sites: Emerging evidence from the savanna region of north east Nigeria. Ghana Journal of Geography, 11(2), pp. 243-263.

Yusuf, M. B., Firuza B. M. and Khairulmaini, O.S . (2015). Survey of rill erosion characteristics of small-scale farmers' crop fields in the northern art of Taraba State, Nigeria. International Journal of Tropical Agriculture, 33(4), pp. 3305-3313.

\section{Cite this article as:}

Babalola, T. S., Ogunleye, K. S., Lawal, J. A. and Ilori, A. O. A, 2021. An Assessment of Degradation of Soil Properties in Kabba College of Agriculture, Kogi State, Nigeria. Nigerian Journal of Environmental Sciences and Technology, 5(1), pp. 102-109. https://doi.org/10.36263/nijest.2021.01.0240 